\title{
The rise of feathered dinosaurs: Kulindadromeus zabaikalicus, the oldest dinosaur with 'feather-like' structures
}

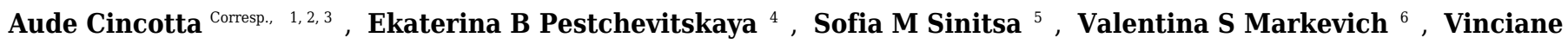
Debaille $^{7}$, Svetlana A Reshetova ${ }^{5}$, Irina M Mashchuk ${ }^{8}$, Andrei O Frolov ${ }^{8}$, Axel Gerdes ${ }^{9}$, Johan Yans ${ }^{2}$, Pascal Godefroit ${ }^{1}$

${ }^{1}$ Directorate 'Earth and History of Life', Royal Belgian Institute of Natural Sciences, Brussels, Belgium

2 Institute of Life, Earth and Environment, University of Namur, Namur, Belgium

3 School of Biological, Earth and Environmental Sciences, University College Cork, Cork, Ireland

${ }^{4}$ Institute of Petroleum Geology and Geophysics. AA Trofimuk, Novosibirsk, Russia

5 Institute of Natural Resources, Ecology, and Cryology, Siberian Branch of the Russian Academy of Sciences, Chita, Russia

${ }^{6}$ Federal Scientific Center of the East Asia Terrestrial Biodiversity, Far East Branch of the Russian Academy of Sciences, Vladivostok, Russia

7 Laboratoire G-Time, Université Libre de Bruxelles, Brussels, Belgium

8 Institute of Earth's Crust, Siberian Branch of the Russian Academy of Sciences, Irkutsk, Russia

9 Institut für Geowissenschaften, Johann Wolfgang Goethe Universität Frankfurt am Main, Frankfurt, Germany

Corresponding Author: Aude Cincotta

Email address: aude.cincotta@ucc.ie

Diverse epidermal appendages including grouped filaments closely resembling primitive feathers in non-avian theropods, are associated with skeletal elements in the primitive ornithischian dinosaur Kulindadromeus zabaikalicus from the Kulinda locality in southeastern Siberia. This discovery suggests that "feather-like" structures did not evolve exclusively in theropod dinosaurs, but were instead potentially widespread in the whole dinosaur clade. The dating of the Kulinda locality is therefore particularly important for reconstructing the evolution of "feather-like" structures in dinosaurs within a chronostratigraphic framework. Here we present the first dating of the Kulinda locality, combining U-Pb analyses (LA-ICP-MS) on detrital zircons and monazites from sedimentary rocks of volcaniclastic origin and palynological observations. Concordia ages constrain the maximum age of the volcaniclastic deposits at $172.8 \pm 1.6 \mathrm{Ma}$, corresponding to the Aalenian (Middle Jurassic). The palynological assemblage includes taxa that are correlated to Bathonian palynozones from western Siberia, and therefore constrains the minimum age of the deposits. The new U-Pb ages, together with the palynological data, provide evidence of a Bathonian age - between $168.3 \pm 1.3 \mathrm{Ma}$ and $166.1 \pm 1.2 \mathrm{Ma}$ - for Kulindadromeus. This is older than the previous Late Jurassic to Early Cretaceous ages tentatively based on local stratigraphic correlations. A Bathonian age is highly consistent with the phylogenetic position of Kulindadromeus at the base of the neornithischian clade and suggests that cerapodan dinosaurs originated in Asia during the Middle Jurassic, from a common ancestor that closely looked like Kulindadromeus. Our results consequently 
show that Kulindadromeus is the oldest known dinosaur with "feather-like" structures discovered so far. 
1 The rise of feathered dinosaurs: Kulindadromeus

2 zabaikalicus, the oldest dinosaur with 'feather-like'

3 structures

4

5 Aude Cincotta Corresp., 1, 2, 3, Ekaterina B Pestchevitskaya ${ }^{4}$, Sofia M Sinitsa ${ }^{5}$, Valentina S

6 Markevich $^{6}$, Vinciane Debaille ${ }^{7}$, Svetlana A Reshetova ${ }^{5}$, Irina M Mashchuk ${ }^{8}$, Andrei O

7 Frolov $^{8}$, Axel Gerdes ${ }^{9}$, Johan Yans ${ }^{2}$, Pascal Godefroit ${ }^{1}$

8

9 'Directorate 'Earth and History of Life', Royal Belgian Institute of Natural Sciences, Brussels,

10 Belgium

$11{ }^{2}$ Institute of Life, Earth and Environment, University of Namur, Namur, Belgium

12 '3school of Biological, Earth and Environmental Sciences, University College Cork, Cork,

13 Ireland

$14{ }^{4}$ Institute of Petroleum Geology and Geophysics. AA Trofimuk, Novosibirsk, Russia

15 Institute of Natural Resources, Ecology, and Cryology, Siberian Branch of the Russian

16 Academy of Sciences, Chita, Russia

$17{ }^{6}$ Federal Scientific Center of the East Asia Terrestrial Biodiversity, Far East Branch of Russian

18 Academy of Sciences, Vladivostok, Russia

$19{ }^{7}$ Laboratoire G-Time, Université Libre de Bruxelles, Brussels, Belgium

$20{ }^{8}$ Institute of Earth's Crust, Siberian Branch of the Russian Academy of Sciences, Irkutsk, Russia

21 Institut für Geowissenschaften, Johann Wolfgang Goethe Universität Frankfurt am Main,

22 Frankfurt, Germany

23

24 Corresponding Author: Aude Cincotta

25 Email address: aude.cincotta@ucc.ie 
39

40

41

42

43

44

45

46

47

48

49

50

51

52

53

54

55

56

57

58

59

60

61

62

63

64

65

66

67

68

69

70

71

72

73

74

75

76

77

\section{Abstract}

Diverse epidermal appendages including grouped filaments closely resembling primitive feathers in non-avian theropods, are associated with skeletal elements in the primitive ornithischian dinosaur Kulindadromeus zabaikalicus from the Kulinda locality in south-eastern Siberia. This discovery suggests that "feather-like" structures did not evolve exclusively in theropod dinosaurs, but were instead potentially widespread in the whole dinosaur clade. The dating of the Kulinda locality is therefore particularly important for reconstructing the evolution of "featherlike" structures in dinosaurs within a chronostratigraphic framework. Here we present the first dating of the Kulinda locality, combining U-Pb analyses (LA-ICP-MS) on detrital zircons and monazites from sedimentary rocks of volcaniclastic origin and palynological observations. Concordia ages constrain the maximum age of the volcaniclastic deposits at $172.8 \pm 1.6 \mathrm{Ma}$, corresponding to the Aalenian (Middle Jurassic). The palynological assemblage includes taxa that are correlated to Bathonian palynozones from western Siberia, and therefore constrains the minimum age of the deposits. The new $\mathrm{U}-\mathrm{Pb}$ ages, together with the palynological data, provide evidence of a Bathonian age - between $168.3 \pm 1.3 \mathrm{Ma}$ and $166.1 \pm 1.2 \mathrm{Ma}$ - for Kulindadromeus. This is older than the previous Late Jurassic to Early Cretaceous ages tentatively based on local stratigraphic correlations. A Bathonian age is highly consistent with the phylogenetic position of Kulindadromeus at the base of the neornithischian clade and suggests that cerapodan dinosaurs originated in Asia during the Middle Jurassic, from a common ancestor that closely looked like Kulindadromeus. Our results consequently show that Kulindadromeus is the oldest known dinosaur with "feather-like" structures discovered so far.

\section{INTRODUCTION}

In 2010, a new Konservat-Lagerstätte was discovered in the Kulinda locality (south-eastern Siberia, Russia) by geologists from the Institute of Natural Resources, Ecology, and Cryology, SB RAS (Chita, Russia). The site has yielded numerous bones and associated integumentary structures belonging to the primitive ornithischian dinosaur, Kulindadromeus zabaikalicus (Godefroit et al., 2014). The soft-tissue remains include well-preserved skin, epidermal scales, and three types of integumentary filaments all tentatively interpreted as feathers (see the 3D reconstruction of the specimen in Fig.S1). Monofilaments in ornithischian dinosaurs were previously reported in the basal ceratopsian Psittacosaurus (Mayr et al., 2002) and in the heterodontosaurid Tianyulong (Zheng et al., 2009). However, the diversity and complexity of the elongated and compound integumentary structures in Kulindadromeus suggest that feather-like structures were likely widespread within the whole dinosaur clade and potentially present in their last common ancestor (Godefroit et al., 2014). According to Alifanov and Saveliev $(2014 ; 2015)$, the dinosaur fauna at Kulinda comprises three new taxa: the 'hypsilophodontian' ornithopods Kulindapteryx ukureica and Daurosaurus olovus (Alifanov \& Saveliev, 2014), and the 'nqwebasaurid' ornithomimosaur Lepidocheirosaurus natalis (Alifanov \& Saveliev, 2015). 
78 However, we consider these three taxa as nomina dubia, and very likely synonyms of

79 Kulindadromeus zabaikalicus (see Supplementary Information for a brief discussion on the 80 composition of the Kulinda dinosaur fauna).

81 The stratigraphic section at Kulinda belongs to the base of the Ukurey Formation in the Olov 82 Depression. K-Ar radiometric analyses on basalts and rhyolites from the base of the Ukurey Fm 83 proposed ages between 153-157 Ma (Kimmeridgian) and 147-165 Ma (Callovian-Berriasian), 84 respectively (Sinitsa, 2011). Palaeo entomological and microfaunal comparisons with the 85 Glushkovo Formation in the Unda-Daya Depression also suggested a Late Jurassic - Early 86 Cretaceous age for the Ukurey Formation (Sinitsa \& Starukhina, 1986; Sinitsa, 2011). The age of 87 the Kulinda deposits has not been directly investigated so far.

88 Here, we refine the age of the Kulinda locality using U-Pb dating of zircons and comparisons of 89 the palynomorph and megafloral assemblages collected from the volcaniclastic layers that have 90 also yielded the Kulindadromeus fossils. Dating of the Kulinda locality is particularly important 91 for a better timing of the evolutionary history of integumentary structures, including feathers, in 92 dinosaurs. Thus, the oldest well-dated integumentary structures in dinosaurs are from paravian 93 theropods (Anchiornis, Xiaotingia, Eosinopteryx, Aurornis, and Serikornis [Hu et al., 2009; Xu 94 et al., 2011; Godefroit et al., 2013a; Godefroit et al., 2013b; Lefèvre et al., 2017]) and in the 95 heterodontosaurid Tianyulong (Zheng et al., 2009) from the Tiaojishan Formation, in the 96 Daxishan section near the town of Linglongta, Jianchang County in western Liaoning 97 Province (China). Recent U-Pb analyses have dated this section as Oxfordian (Late Jurassic), 98 with an age ranging between $160.254 \pm 0.045 \mathrm{Ma}$ and $160.889 \pm 0.069 \mathrm{Ma}$ (Chu et al., 2016). 99 The present paper describes the depositional history of the Kulinda section and provides data 100 about the age of the neornithischians and the implication of this for the early evolution of 101 feathers in dinosaurs.

102

103

104

105

106

107

108

109

110

111

112

113

114

115

116

117

\section{GEOLOGICAL SETTING}

The Kulinda locality (Fig. 1A) is situated between two major fault zones related to the closure of the Mongol-Okhotsk Ocean that likely took place in south-eastern Siberia at the Early-Middle Jurassic boundary (Zorin, 1999; Zorin et al., 2001), or during the early Middle Jurassic (Jolivet et al., 2013; see also the Supplementary Text). Both fault zones delimit a series of grabens in the area. The excavated sections at Kulinda belong to the lower part of the Ukurey Formation that crops out in the Olov Valley and several other isolated depressions in the central and southeastern Transbaikal region (Rudenko \& Starchenko, 2010). The formation is composed of interbedded sandstones, tuffaceous sandstones, conglomerates, tuffaceous conglomerates, siltstones, breccia, andesites, basaltic trachyandesites, basaltic andesites, and tuffs, up to a thickness of 850 metres (Anashkina et al., 1997). The geological map of the Transbaikal region indicates that Upper Jurassic volcaniclastic deposits crop out in Kulinda area (Fig. 1B). Field work conducted in this area and described in 2011 in a local - unpublished - report identified the remains of a volcanic edifice, named "Pharaoh", ca. five kilometers south of the Kulinda locality (Kozlov, 2011). That structure is still clearly visible in the landscape (Fig. S2). The report notes 
118 that trachyandesites from the Pharaoh volcano have been collected on the left bank of the Olov

119 River, and were dated at $180 \pm 5$ and $188 \pm 6$ Ma by K-Ar methods (Kozlov et al., 2011). In the

120 same report, K-Ar dating of other volcanic rocks, this time collected on the right bank of the

121 Olov River, indicate younger ages $(155 \pm 5.0 \mathrm{Ma}, 104 \pm 3.0 \mathrm{Ma}$, and $103 \pm 4.0 \mathrm{Ma})$. The wide

122 age range reported for the volcanic rocks collected on the Pharaoh complex suggests several

123 volcanic episodes in the area from the Early Jurassic up to the Early Cretaceous.

124 Felsic igneous rocks are exposed on top of the Kulinda hill and consist of granites, biotite

125 granites, and biotite-quartz monzonites (see Table S1 and Fig. S3). These plutonic rocks likely

126 constitute an outcropping part of the basement. The Kulinda stratigraphical section mainly

127 consists of a heterogeneous succession of volcaniclastic deposits (Fig. 2A). It comprises: (1)

128 thinly laminated mudstones, (2) a single layer of tuffaceous siltstones showing glass shards, (3)

129 lithic arenites (sandstones) including reworked fragments mainly of volcanic origin, (4)

130 greywackes (matrix-supported) and feldspathic arenites (grain-supported) of silt- and sand-sizes,

131 and (5) coarse- grained to brecciated sandstones mainly composed of automorph quartz and

132 feldspars (see Figs. S4 and S5). Excavations at Kulinda consisted of three parallel trenches

133 located at successive altitudes on the southern slope of the hill (Fig. 2B). The rock layers dip 20-

$13430^{\circ}$ to the south. The trenches are not correlated laterally due to their poor exposure. The vertical

135 stratigraphic distances were therefore estimated by means of rock dip and horizontal distances

136 between the trenches, and correspond to ca. 11-17 $\mathrm{m}$ between trench 4 and trench $3 / 3$, and ca.

$13736-58 \mathrm{~m}$ between trench $3 / 3$ and trench 3 . Deposits from trench 4 are considered to be the oldest,

138 being on the lowest part of the slope (altitude $680 \mathrm{~m}$ ), deposits from trench $3 / 3$ are intermediate

139 (alt. $690 \mathrm{~m}$ ), and those from trench 3 are located higher up on the hill (alt. $720 \mathrm{~m}$; Fig. 2B-C).

140 Trench 4 and trench 3 are laterally separated by about 130 metres (Fig. 2B).

141

142

\section{MATERIALS \& METHODS}

143

\section{U-Pb geochronology}

146

147

148

149

150

151

152

153

154

155

156

Zircons were sampled from volcaniclastic sandstones in two different locations: (1) in the lowest part of trench 4, beneath the bone bed 4, and 2) in the medial part of trench 3, beneath the bone bed 3. Both zircons and monazites were sampled in granites cropping out on top of the Kulinda hill. The samples were prepared for mineral separation at the 'Laboratoire G-Time' (Université Libre de Bruxelles, Brussels). The rocks were previously fragmented by Selfrag ${ }^{\circledR}$ high voltage pulse to liberate intact grains. Zircons and monazites were then separated by standard methods using heavy liquids, hand-picked under a binocular microscope, mounted on epoxy resin, and eventually polished.

Uranium, thorium and lead isotope analyses were carried out by laser ablation - inductively coupled plasma - mass spectrometry (LA-ICP-MS) at the Goethe University of Frankfurt (GUF), using a slightly modified method, described in (Gerdes \& Zeh 2006; 2009). A ThermoScientific 
158 Technic, Australia). The laser was fired with $5.5 \mathrm{~Hz}$ at a fluence of about $2-3 \mathrm{~J} . \mathrm{cm}^{-2}$. The above

159

160

161

162

163

164

165

166

167

168

169

170

171

172

173

174

175

176

177

178

179

180

181

182

183

184

185

186

187

188

189

190

191

192

193

194

195

196

configuration, with a spot size of $30 \mu \mathrm{m}$ and depth penetration of $0.6 \mu \mathrm{m} \cdot \mathrm{s}^{-1}$, yielded a sensitivity of $11000-14000 \mathrm{cps} / \mathrm{ppm}{ }^{238} \mathrm{U}$. Raw data were corrected offline for background signal, common $\mathrm{Pb}$, laser induced elemental fractionation, instrumental mass discrimination, and time-dependent elemental fractionation of $\mathrm{Pb} / \mathrm{U}$ using an in-house MS Excel $\odot$ spread-sheet program (Gerdes \& Zeh 2006; 2009). Laser-induced elemental fractionation and instrumental mass discrimination were corrected by normalization to the reference zircon GJ-1 ( $0.0982 \pm 0.0003$; ID-TIMS GUF value). Repeated analyses of the reference zircon Plesovice and BB-16 and reference monazite Itabe and Manangotry (Gerdes \& Zeh 2006) during the same analytical sessions yielded an accuracy of better $1 \%$. All uncertainties are reported at the 2 SD level. CL imaging of the minerals could not be performed due to technical issues but backscattered electron (EBS) imaging was done instead (Fig. S6).

\section{Palynology}

A total of eleven samples were chosen for palynological analyses, one from trench 3 , four from trench $3 / 3$, and six from trench 4 . First, $25 \mathrm{~g}$ of sediment were separated from each sample, washed under water and crushed into gravel-sized fragments (about $2 \mathrm{~mm}$ ), immersed in 15\% $\mathrm{HCl}$, followed by $30 \% \mathrm{HF}$, and finally in warm $10 \% \mathrm{HCl}$. A $12 \mu \mathrm{m}$ filter was used to isolate the palynomorphs from the coarser grains. Palynological preparations for palynofacies were directly mounted on slides, although samples for organic preparations were further exposed in $\mathrm{HNO}_{3}$ for two minutes. Observation of palynological preparations was carried out using a Zeiss optical microscope and microphotographs were taken with an Infinity X (Lumenera) camera using Deltapix software.

\section{RESULTS}

\section{U-Pb geochronology}

${ }^{206} \mathrm{~Pb} / 238 \mathrm{U}$ data obtained for the granite and two volcaniclastic samples are given in Table S2. ${ }^{206} \mathrm{~Pb} /{ }^{238} \mathrm{U}$ ages of individual zircons and monazites range between $171.1 \pm 1.5 \mathrm{Ma}$ and $189.3 \pm$ $1.5 \mathrm{Ma}$, with the highest age probability around $172-173 \mathrm{Ma}$ (Fig. 3). Two age populations are recognized in the volcaniclastic deposits: an 'old' one (1) $183.8 \pm 1.8-189.3 \pm 1.5 \mathrm{Ma}$, and a younger one (2) $171.1 \pm 1.5-177.6 \pm 1.7 \mathrm{Ma}$. The granite has one age population, at $172.8 \pm 1.6$ Ma that is interpreted as its crystallization age. Results of ${ }^{206} \mathrm{~Pb} /{ }^{238} \mathrm{U}$ dating of the three samples have been plotted on three distinct concordia curves (Fig. 4A-C), one for each sample. Analyses of single zircons from T4-3, T3-7, and the granite, yield mean ${ }^{206} \mathrm{~Pb} /{ }^{238} \mathrm{U}$ ages of: (1) $173.0 \pm 1.6$ $\mathrm{Ma}$ (mean square of weighted deviates, MSWD =0.89), (2) $172.8 \pm 1.5 \mathrm{Ma}(\mathrm{MSWD}=1.1$ ), and (3) $172.5 \pm 1.6 \mathrm{Ma}(\mathrm{MSWD}=0.95)$, respectively. 
197

198

199

200

201

202

203

204

205

206

207

208

209

210

211

212

213

214

215

216

217

218

219

220

221

222

223

224

225

226

227

228

229

230

231

232

233

234

235

236

\section{Palynology and paleobotany}

The distribution of palynological taxa recovered from the three trenches examined is shown in Figure 5. Two samples collected from trench $3 / 3$ and two samples from trench 3 (Fig. 5, G, I, K, and $\mathrm{L}$ ) do not contain palynomorphs. This probably represents a taphonomic bias partly related to the coarse-grained character of the deposits, less favorable to the accumulation of thin-walled spores and pollen grains (Batten, 1996; Traverse, 1988). The eight remaining samples contain spore-pollen spectra mostly represented by poorly preserved gymnosperm pollen. The sporepollen spectrum from trench 4 is more diverse, and all collected samples contained palynomorphs. Figure 6 shows selected palynomorphs from Kulinda deposits and all the taxa are listed with authors and year of publication in Table S3. Bisaccate morphotypes include high percentages of Pseudopicea spp. (5-19\%), Pseudopicea variabiliformis (8-12\%), and Pseudopicea grandis (3-7\%). Pollen morphotypes closer to recent forms are rare and represented by the genera Piceapollenites (1-1.5\%) and Pinuspollenites (11.5\%). Alisporites spp. and Podocarpidites spp. are also rare. Common components of the assemblage are Ginkgocycadophytus spp. (1-7\%) and Cycadopites spp. (0.5-2.5\%). Classopollis pollen are rather scarce at Kulinda (1-5\%). Spore abundance is variable but is in general higher than that for pollen. Spores are dominated by Stereisporites spp. (1-19\%), Cyathidites australis (2.5-9\%), and Cyathidites minor (1.5-4\%).

Besides the major taxa listed above, the assemblage also includes rare occurrences of the pollen Alisporites bisaccus, Dipterella oblatinoides, Piceites podocarpoides, Protoconiferus funarius, Protopicea cerina, Protopinus subluteus, Pseudopiceae monstruosa, Pseudopinus spp, Dacrydiumites spp., Pinus divulgata, P. incrassata, P. pernobilis, P. subconcinua, P. vulgaris, Podocarpidites multesimus, $P$. major, Sciadopityspollenites multiverrucosus, and taxa of uncertain affinity such as Callialasporites dampieri and Podozamites spp. Rare specimens of spores include the lycopods Annulispora folliculosa, Densoisporites velatus, Leptolepidites verrucatus, Neoraistrickia aff. taylorii, Perotrilites sp., Polycingulatisporites triangularis, Retitriletes subrotundus, Undulatisporites pflugii, U. fossulatus, Uvaesporites scythicus, the ferns Dictyophyllidites equiexinus, Eboracia granulosa, Gleicheniidites sp., Leiotriletes nigrans, L. pallescens, L. selectiformis, L. subtilis, Osmunda papillata, Osmundacidites jurassicus, Salvinia sp., the bryophytes Stereisporites infragranulatus, the horsetail Equisetites variabilis, and Acanthotriletes spp. and Punctatosporites scabratus, both of unclear affinities. The assemblage also contains very rare trilete, zonate spores of rather simple morphology resembling the genera Couperisporites, Kraeuselisporites, or the taxon Aequitriradites norrisii (see Fig. 6$\mathrm{U})$.

\section{DISCUSSION}

The Kulinda deposits were previously regarded as Late Jurassic to Early Cretaceous, based on palaeontological comparisons and on the relative position of the section within the Ukurey Formation (Kozlov et al., 1998; Rudenko \& Starchenko, 2010). The new U-Pb radiometric 
237

238

239

240

241

242

243

244

245

246

247

248

249

250

251

252

253

254

255

256

257

258

259

260

261

262

263

264

265

266

267

268

269

270

271

272

273

274

275

276

investigations obtained here from Kulinda deposits provide direct evidence that can constrain the age of the locality.

Given the sedimentary origin of the deposits, the radiometric analyses give an indication of their maximal age. The Concordia ages for zircons and monazites (Fig. 4) recovered from both the volcaniclastics and the granite suggest an Aalenian (Middle Jurassic) age. We interpret the older age population in the volcaniclastic sediments as possibly representing inherited zircons from the granite or detrital zircons coming from another granitic source not sampled here. Chemical analyses (more information available in the Supplementary Methods) performed on rock samples collected from the stratigraphic section shows that the sedimentary deposits are very similar in composition (see Table S4 and Fig. S7), indicating a similar source for all the deposits. This is also evidenced by the rare earth element (REE) pattern between the deposits and the granitic basement (see Fig. S6). Even if no zircon older than 173.4 \pm 3.7 Ma has been sampled in the present study in the granite, our data suggest that the deposits at Kulinda, including the bone beds, are composed of material reworked from the nearby granitoids, cropping out on top of the hill. When only looking at the youngest zircon population, the three samples display a concordant age within error at 172.5 $\pm 1.6 ; 173.0 \pm 1.6$ and 172.8 $\pm 1.5 \mathrm{Ma}$ (Fig.4). This also emphasizes the genetic relationship between the granite and the volcaniclastic sediments from the bone beds. Consequently, the average age of $172.8 \pm 1.6 \mathrm{Ma}$ indicates the maximum age of the volcaniclastic sediments, which corresponds to the Aalenian.

The volcaniclastic origin of the deposits at Kulinda, together with the chemical and age for the granite suggest that the Kulinda deposits accumulated from the reworking of, at least, that Aalenian igneous source at the site of deposition. We cannot exclude the possibility that another igneous source yielded the older population of zircon, but this source must be chemically similar to the granite in any case. Because of the volcaniclastic nature of the Kulinda deposits, palynological information provides an essential complement to the radiometric data for refining the age of the deposits. The palynomorph distribution reflects the distribution of the taxa in the environment at the moment of sediment deposition whereas the absolute age of the zircons and monazites gives the crystallization age of the granitic source of the deposits.

Most of the palynomorphs recovered at Kulinda are characterized by wide stratigraphic ranges through both Jurassic and Cretaceous deposits (e.g., Norris, 1965; Cornet, Traverse \& McDonald, 1973; Filatoff, 1975; Higgs \& Bees, 1986; Ilyina, 1986; Markevich, 1995; Li \& Batten, 2004; Pestchevitskaya, 2007; Ribecai, 2007; Markevich \& Bugdaeva, 2009; Ercegovac, 2010; Lebedeva \& Pestchevitskaya, 2012; Kujau et al., 2013; Zhang et al., 2014; Slater et al., 2018; Shevchuk, Slater \& Vajda, 2018). The spore and pollen taxa observed in the Kulinda deposits are reported in Middle Jurassic palynozones that are calibrated to ammonite biozones from marine sections (Ilyina, 1986) and palaeofaunas from continental strata (Starchenko, 2010). In northern Siberia, the appearance of Pinus divulgata is attested in the Bajocian but the taxon is common elsewhere, from the Triassic through the Cretaceous; Alisporites bisaccus and Podocarpidites rousei are both reported in Bajocian deposits from Siberia and western Canada (Ilyina, 1986), although $A$. bisaccus has a much wider stratigraphic range and $P$. rousei is typical 
277 for the Bathonian of western Siberia and the Kansk-Achinsk Basin in southwestern Siberia 278 (Krasnoyarsk region; Smokotina, 2006). The stratigraphically important taxa recovered from 279 Kulinda deposits are Podocarpidites rousei, Eboracia torosa, and Gleicheniidites spp. These 280 species are typical for the Bathonian in southern and northern regions of western Siberia (Ilyina, 281 1985; Shurygin et al., 2010) and Kansk-Achinsk Basin (Smokotina, 2006). Palynozone 10 from 282 these regions includes Cyathidites spp., Sciadopityspollenites macroverrucosus, Eboracia torosa, 283 and Classopollis, and a local palynozone includes Eboracia torosa, Quadraeculina limbata, and 284 Classopollis. The strong domination of Pseudopicea variabiliformis is a characteristic feature of 285 Bathonian assemblages, although this pollen is also abundant in older strata. Note that in western 286 Siberia, the stratigraphic position of the palynozones is controlled by ammonites and 287 foraminifers, and is therefore considered robust. Small pollen grains resembling Podocarpidites 288 rousei are reported in assemblages from the middle part of the Bajocian of northern Siberia 289 (Ilyina, 1985), but it is a characteristic pollen for Bathonian deposits in southern Siberia. 290 Eboracia torosa is a Bathonian species (Ilyina, 1985), although the possibility that the taxon 291 appeared earlier in other regions cannot be excluded. Gleicheniidites is an important component 292 of the Kulinda assemblage. Its lowermost occurrences are defined in Bathonian sediments dated 293 by macro- and microfauna in the East-European Platform (Starchenko, 2010). This taxon has 294 also been reported in Bathonian siliciclastic sediments from northeastern Ukraine (Shevchuk, 295 Slater \& Vajda, 2018). Another key feature is the low abundance of Classopollis spp., which 296 excludes a Callovian age, characterized by high percentages of this pollen in the Siberian 297 palaeofloristic region (Ilyina, 1985; Smokotina, 2006; Starchenko, 2010). It is interesting to note 298 the presence of trilete zonate spores resembling Aequitriradites norrisii, which is an important 299 species for the Middle Jurassic of Australia. Its lowermost occurrences are there revealed in the 300 Bathonian, where the eponymous zone is defined for the middle part of this stage (Sajjadi \& 301 Playford, 2002). Nevertheless, an accurate determination of this taxon is not possible in the 302 Kulinda material due to poor preservation.

303 Combination of the data recovered from the three examined trenches at Kulinda suggests that the 304 deposits indicate a Bathonian age.

305 It should be noted that the macrofloral assemblages from Kulinda are similar in the different 306 horizons where they were collected. Their taxonomic composition is characteristic for the 307 Middle Jurassic - Early Cretaceous time range in Siberia, but do not provide more precise 308 information about the age of the deposits. We will therefore not discuss this further in the main 309 manuscript but a complete description of the macroflora is available in the Supplementary 310 Material.

311 312

\section{CONCLUSIONS}

314 The deposits from the Kulinda section belong to the lower part of the Ukurey Formation, which

315 crops out in several isolated depressions in the central and southeast Transbaikal region

316 (Rudenko \& Starchenko, 2010; Starchenko, 2010). The age of the Ukurey Formation was 
317 previously regarded as Late Jurassic to Early Cretaceous, based on biostratigraphic comparisons 318 and local correlations. Previous radiochronological studies of volcanic rocks from the formation 319 (with no clear location) indicated a Late Jurassic age (Rudenko \& Starchenko, 2010; Starchenko, 320 2010). Our new results, combining absolute dating and palynological observations, place for the 321 first time age constraints on the dinosaur-bearing volcaniclastics in Kulinda. The absolute dating 322 of igneous and volcaniclastic rocks collected at Kulinda, indicate a maximal Aalenian age (172.8 $323 \pm 1.6 \mathrm{Ma}$ ) for the deposits that have yielded the Kulindadromeus fossils. Palynological data 324 support a Bathonian age for the deposits, corresponding to an age ranging between 168.3 and 325 166.1 Ma (Gradstein et al., 2012), hence giving a minimum age. The stratigraphic range of the 326 Ukurey Formation is therefore wider than previously assumed, its lower part extending to the 327 Middle Jurassic. However, this new observation does not contradict the general geological framework of the region, characterized by marine deposits until the early Middle Jurassic, followed by continental sedimentation in grabens (Mushnikov, Anashkina \& Oleksiv, 1966; Rudenko \& Starchenko, 2010; Starchenko, 2010).

331 A Middle Jurassic age for Kulindadromeus is consistent with its phylogenetic position (see Fig.

333

334 335 336

337

338

339

340

341

342

343

344

345

346

347

348

349

350

351

352

353

354

355

356 S8). A consistent and pectinate scheme of Middle Jurassic Asian basal neornithischians, including Agilisaurus louderbacki, Hexinlusaurus multidens and Kulindadromeus zabaikalicus, form a stem lineage culminating in Cerapoda (Godefroit et al., 2014): Parasaurolophus walkeri Parks, 1922, Triceratops horridus Marsh, 1889, their most recent common ancestor and all descendants (Butler, Upchurch \& Norman, 2008). Agilisaurus and Hexinlusaurus were discovered in the lower member of the Shaximiao Formation of Dashanpu, Sichuan Province, China (Barrett, Butler \& Knoll, 2005), and should therefore be Bajocian-Bathonian in age (Li, Yang \& Hu, 2011). Yandusaursaurus hongheensis, from the upper member of the Shaximiao Formation of Dashampu (Bathonian-Callovian; [Li, Yang \& Hu, 2011]) is not included in this analysis, but is also regarded as closely related to Agilisaurus and Hexinlusaurus (Boyd, 2015). In this phylogenetic scheme, Kulindadromeus is regarded as the sister-taxon of the vast clade Cerapoda. Cerapodan dinosaurs were particularly successful during the Cretaceous, being for example represented by pachycephalosaurs, ceratopsians, and iguanodontians (including the 'duck-billed' hadrosaurs). The earliest records of cerapodans are the dryosaurid iguanodontian Callovosaurus leedsi, from the Callovian of England (Ruiz-Omeñaca, Pereda Suberbiola \& Galton, 2006), and the basal ceratopsian Yinlong downsi, from the Oxfordian of the Junggar Basin, Xinjiang, China (Xu et al., 2006). The calibrated phylogeny of ornithischian dinosaurs therefore suggests that cerapodans originated in Asia during the Middle Jurassic, from a common ancestor that closely looked like Kulindadromeus, then rapidly migrated to Europe, North America and Africa at the end of the Middle Jurassic and during the Late Jurassic. Kulindadromeus is therefore the oldest known dinosaur with "feather-like" structures. The other Jurassic formations that have also yielded fossils of 'feathered' dinosaurs are younger. Recent U$\mathrm{Pb}$ zircon CA-ID-TIMS data from Jianchang support a post-Middle Jurassic, Oxfordian ( 160 $\mathrm{Ma}$ ), age for the Yanliao Biota preserved in the Lanqi/Tiaojishan Fm in western Liaoning (China; [Li, Yang \& Hu, 2011]). Based on strong similarities of the fauna, together with 
357

358

359

360

361

362

363

364

365

366

367

368

369

370

371

372

373

374

375

376

377

378

379

380

381

382

383

384

385

386

387

388

389

390

391

392

393

394

395

396

397

398

available radioisotopic age evidence, it is generally accepted that the Lanqi Fm in Ningcheng (southeastern Inner Mongolia), and the Tiaojishan Fm in northern Heibei should be coeval with the Lanqi/Tiaojishan Fm in Jianchang (Zhou, Jin \& Wang, 2010; Liu et al., 2012; Sullivan et al., 2014), thus also Oxfordian in age ( $\mathrm{Li}$, Yang \& Hu, 2011). The lithographic limestones from Solnhofen and adjacent areas in South Germany that yield Archaeopteryx are early Tithonian in age (Schweigert, 2007).

The discovery of elongated and compound integumentary structures in the Middle Jurassic basal ornithischian Kulindadromeus will undoubtedly orient future research on the origin of feathers, which should be sought in much older deposits. If it can definitely be demonstrated that those structures are homologous to the feathers in theropods, the origin of feathers should be tracked back to the common ancestor of both dinosaur lineages (Godefroit et al., 2014) that most likely lived, regardless of the phylogenetic scenario considered for the relationships of the major dinosaur clades, during the Middle Triassic (Baron, Norman \& Barrett, 2017).

\section{ACKNOWLEDGEMENTS}

We would like to thank the reviewers for their helpful comments, which improved this paper. We gratefully thank Cyrille Prestianni and Paolo Spagna (RBINS) for the fruitful discussions and their help with various analyses. Gaëtan Rochez (University of Namur) and Thomas Goovaerts (RBINS) are thanked for their technical support. Maria McNamara (UCC) is warmly thanked for her advice and our fruitful discussions.

\section{REFERENCES}

Alifanov VR \& Saveliev SV. 2014. Two new ornithischian dinosaurs (Hypsilophodontia, Ornithopoda) from the Late Jurassic of Russia. Paleontological Journal 48:414-425 DOI: $10.1134 / \mathrm{S} 0031030114040029$.

Alifanov VR \& Saveliev SV. 2015. The most ancient Ornithomimosaur (Theropoda, Dinosauria), with cover imprints from the Upper Jurassic of Russia. Paleontological Journal 49:636 DOI: 10.1134/S0031030115060039.

Anashkina KK, Butinm KS, Enikeev FI, Kineakin SV, Krasnov VP, Krivenko VA, Alekseev BI, Pinaeva TA, Rutchtein IG, Semyonov VN, Starukhina LN, Chaban NN \& Shulika EV. 1997. Geological structure of Chita region. Explanatory note to the geological map at 1:500000 scale (Committee on Geology and Mineral Wealth Exploitation of Chita Region). $239 \mathrm{p}$.

Baron MG, Norman DB \& Barrett PM. 2017. A new hypothesis of dinosaur relationships and early dinosaur evolution. Nature 543:501-506 DOI: 10.1038/nature21700.

Barrett PM, Butler RJ \& Knoll F. 2005. Small-bodied ornithischian dinosaurs from the Middle Jurassic of Sichuan, China. Journal of Vertebrate Paleontology 25:823-834 DOI: 10.1671/0272-4634(2005)025[0823:SODFTM]2.0.CO;2. 
399

400

401

402

403

404

405

406

407

408

409

410

411

412

413

414

415

416

417

418

419

420

421

422

423

424

425

426

427

428

429

430

431

432

433

434

435

436

437

438

439

440

441

442

443

Batten DJ. 1996. Palynofacies. Palynology: principles and applications 3:1011-1084.

Boyd CA. 2015. The systematic relationships and biogeographic history of ornithischian dinosaurs. PeerJ 3:e1523 DOI: 10.7717/peerj.1523.

Butler RJ, Upchurch P \& Norman DB. 2008. The phylogeny of the ornithischian dinosaurs. Journal of Systematic Palaeontology 6:1-40 DOI:10.1017/S1477201907002271.

Chu Z, He H, Ramezani J, Bowring SA, Hu D, Zhang L, Zheng S, Wang X, Zhou Z, Deng C \& Guo J. 2016. High-precision U-Pb geochronology of the Jurassic Yanliao Biota from Jianchang (western Liaoning Province, China): Age constraints on the rise of feathered dinosaurs and eutherian mammals. Geochemistry, Geophysics, Geosystems 17:39833992. DOI: $10.1002 / 2016 \mathrm{GC} 006529$.

Cornet B, Traverse A \& McDonald NG. 1973. Fossil spores, pollen, and fishes from Connecticut indicate Early Jurassic age for part of the Newark Group. Science 182:1243-1247 DOI: 10.1126/science.182.4118.1243.

Ercegovac MD. 2010. The age of the Dinaride Ophiolite Belt: Derived olistostrome melange at the northern slope of Moračka Kapa (Montenegro). Geoloski anali Balkanskoga poluostrva 71:37-51 DOI: 10.2298/GABP1071037E.

Filatoff J. 1975. Jurassic palynology of the Perth Basin, western Australia. Palaeontographica Abteilung B 154(1-4):1-113

Gerdes A \& Zeh A. 2006. Combined U-Pb and Hf isotope LA-(MC-) ICP-MS analyses of detrital zircons: Comparison with SHRIMP and new constraints for the provenance and age of an Armorican metasediment in Central Germany. Earth and Planetary Science letters 249:47-62 DOI: 10.1016/j.epsl.2006.06.039.

Gerdes A \& Zeh A. 2009. Zircon formation versus zircon alteration - New insights from combined U-Pb and Lu-Hf in-situ La-ICP-MS analyses of Archean zircons from the Limpopo Belt. Chemical Geology 261:230-243 DOI: 10.1016/j.chemgeo.2008.03.005.

Godefroit P, Cau A, Hu D, Escuillie F, Wenhao W \& Dyke G. 2013a. A Jurassic avialan dinosaur from China resolves the early phylogenetic history of birds. Nature 498:359-362 DOI: $10.1038 /$ nature12168.

Godefroit P, Demuynck H, Dyke G, Hu D, Escuillié F, \& Claeys P. 2013b. Reduced plumage and flight ability of a new Jurassic paravian theropod from China. Nature Communications 4:1394 DOI: 10.1038/ncomms2389.

Godefroit P, Sinitsa SM, Dhouailly D, Bolotsky YL, Sizov AV, McNamara ME, Benton MJ \& Spagna P. 2014. A Jurassic ornithischian dinosaur from Siberia with both feathers and scales. Science 345:6 DOI: 10.1126/science.1253351.

Gradstein FM, Ogg JG, Schmitz M \& Ogg G. 2012. The geologic time scale 2012. Elsevier. Higgs K \& Beese APA. 1986. Jurassic microflora from the Colbond Clay of Cloyne, County Cork. Irish Journal of Earth Sciences 7(2):99-109

$\mathrm{Hu} \mathrm{D}$, Houl L, Zhang L \& Xu X. A pre-Archaeopteryx troodontid theropod from China with long feathers on the metatarsus. Nature 461(7264) DOI:10.1038/nature08322 (2009).

Ilyina VI. 1985. Jurassic Palynology of Siberia. Nauka.

Ilyina VI. 1986. Subdivision and correlation of the marine and non-marine Jurassic sediments in Siberia based on palynological evidence. Review of Palaeobotany and Palynology 46: 357-364.

Jolivet M, Arzhannikov S, Chauvet A, Arzhannikova A, Vassallo R, Kulagina N \& Akulova V. 2013. Accomodating large-scale intracontinental extension and compression in a single 
444

445

446

447

448

449

450

451

452

453

454

455

456

457

458

459

460

461

462

463

464

465

466

467

468

469

470

471

472

473

474

475

476

477

478

479

480

481

482

483

484

485

486

487

488 stress-field: a key example from the Baikal Rift System. Gondwana Research 24:918-935 DOI: 10.1016/j.gr.2012.07.017.

Kozlov SA, Zaikov EA \& Karasev VV. 1998. Legend of the Olekminsky series, Geological map of the Russian Federation, scale 1:200 000. 195 (Chita).

Kozlov SA. 2011. Report on the results of field work on facility no. 5 "GDP-200, sheet N50XXXII, -XXXIII" (Vershino-Darasunsky area) (Chita).

Kujau A, Heimhofer U, Hochuli PA, Pauly S, Morales C, Adatte T, Föllmi K, Ploch I \& Mutterlose J. 2013. Reconstructing Valanginian (Early Cretaceous) mid-latitude vegetation and climate dynamics based on spore-pollen assemblages. Review of Paleobotany and Palynology 197:50-69 DOI:10.1016/j.revpalbo.2013.05.003.

Lebedeva NK \& Pestchevitskaya EB. 2012. Reference Cretaceous spore-pollen succession of West Siberia: evolutionary stages, facies, and correlations. Journal of Stratigraphy 36(2): 193-212.

Lefèvre U, Cau A, Cincotta A, Hu D, Chinsamy A, Escuillié F \& Godefroit P. 2017. A new Jurassic theropod from China documents a transitional step in the macrostructure of feathers. The Science of Nature 104:74 DOI: 10.1007/s00114-017-1496-y.

Li J \& Batten DJ. 2004. Early Cretaceous palynofloras from the Tanggula Mountains of the northern Qinghai-Xizang (Tibet) Plateau, China. Cretaceous Research 25:531-542 DOI: 10.1016/j.cretres.2004.04.005.

Li K, Yang C \& Hu F. 2011. Dinosaur assemblages from the Middle Jurassic Shaximiao Formation and Chuanjie Formation in the Sichuan-Yunnan Basin, China. Volumina Jurassica 9(9):21-42.

Liu YQ, Kuang HW, Jiang XJ, Peng N, Xu H \& Sun HY. 2012. Timing of the earliest known feathered dinosaurs and transitional pterosaurs older than the Jehol Biota.

Palaeogeography, Palaeoclimatology, Palaeoecology 323:1-12 DOI: 10.1016/j.palaeo.2012.01.017.

Markevich VS. 1995. Cretaceous palynoflora of northeastern Asia. Vladivostok: Dalnauka, 200. Markevich VS \& Bugdaeva EV. 2009. Palynological evidence for dating Jurassic-Cretaceous boundary sediments in the Bureya basin, Russian Far East. Russian Journal of Pacific Geology 3:284-293.

Mayr G, Peters DS, Plodowski G \& Vogel O. 2002. Bristle-like integumentary structures at the tail of the horned dinosaur Psittacosaurus. Naturwissenschaften 89:361-365 DOI:10.1007/s00114-002-0339-6.

Mushnikov AF, Anashkina KK \& Oleksiv BI. 1966. Stratigraphy of Jurassic sediments in the eastern Trans-Baikal region. Bulletin of Geology and Mineral Resources of the Chita Region 2:57-99.

Norris G. 1965. Triassic and Jurassic miospores and acritarchs from the Beacon and Ferrar groups, Victoria Land, Antarctica. New Zealand journal of geology and geophysics 8: 236-277.

Pestchevitskaya EB. 2007. Lower Cretaceous biostratigraphy of Northern Siberia: palynological units and their correlation significance. Russian Geology and Geophysics 48:941-959 DOI: $10.1016 /$ j.rgg.2007.10.4004.

Ribecai C. 2007. Early Jurassic miospores from Ferrar Group of Carapace Nunatak, South Victoria Land, Antarctica. Review of Palaeobotany and Palynology 144:3-12 DOI:10.1016/j.revpalbo.2005.09.005. 
489

490

491

492

493

494

495

496

497

498

499

500

501

502

503

504

505

506

507

508

509

510

511

512

513

514

515

516

517

518

519

520

521

522

523

524

525

526

527

528

529

530

531

532

Rudenko VE \& Starchenko VV. 2010. Explanatory note to the geological map of the Russian Federation. Aldan-Transbaikalian Series. Sheet N-50 - Sretensk. 377 (Saint-Petersburg). Ruiz-Omeñaca JI, Pereda Suberbiola X \& Galton PM. 2006. In Horns and Beaks: Ceratopsian and ornithopod dinosaurs 3.

Sajjadi F \& Playford G. 2002. Systematic and stratigraphic palynology of Late Jurassic-earliest Cretaceous strata of the Eromanga Basin, Queensland, Australia: Part one, 1-112.

Schweigert G. 2007. Ammonite biostratigraphy as a tool for dating Upper Jurassic lithographic limestones from South Germany-first results and open questions. Neues Jahrbuch für Geologie und Paläontologie-Abhandlungen 245:117-125. DOI:10.1127/00777749/2007/0245-0117.

Shevchuk O, Slater SM, Vajda V. 2018. Palynology of Jurassic (Bathonian) sediments from Donbas, northeast Ukraine. Palaeobiodiversity and Palaeoenvironments 98(1):153-164. DOI:10.1007/s12549-017-0310-3.

Shurygin BN, Nikitenko BL, Devyatov VP, Il'ina VI, Meledina SV, Gaideburova EA, Dzyuba OS, Kazakov AM, Mogucheva NK. 2000. Stratigraphy of Oil and Gas Basins of Siberia: The Jurassic System [in Russian]. Izd. SO RAN, Filial "Geo" (Novosibirsk).

Sinitsa SM \& Starukhina S. 1986. Novye dannye po geologii Zabaikal'ya (Ministry of Geology, Russian Soviet Federative Socialist Republic), 46-51.

Sinitsa SM. 2011. Environmental Cooperative Studies in the Cross-Border Ecological Region: Russia, China, and Mongolia. 173-176 (Institute of Natural Resources, Ecology and Cryology, Siberian Branch of the Russian Academy of Sciences).

Sinitsa SM. 2011. Transitional horizons in the stratigraphy of the Upper Mesozoic of Transbaikalia. Bulletin of Chita State University 70:98-103.

Slater SM, Wellman CH, Romano M, Vajda V. 2018. Dinosaur-plant interactions within a Middle Jurassic ecosystem - palynology of the Burniston Bay dinosaur footprint locality, Yorkshire, UK. Palaeobiodiversity and Palaeoenvironments 98:139-151. DOI: 10.1007/s 12549-017-0309-9.

Smokotina IV. 2006. Palynostratigraphy of Jurassic deposits of Kansk-Achinsk Basin, (Krasnoyarskgeolsjomka, Krasnoyarsk).

Starchenko VV. 2010. Geological map of Russian federation. Aldan-Transbaikalia series. List M-50, Borzya. Explanatory note [Gosudarstvennaya geologicheskaya karta Rossiyskoy Federatcii. Seriya Aldano-Zabaikalskaya. List M50 - Borzya. Ob’yasnitelnaya zapiska]. 553 (Saint-Petersburg).

Sullivan C, Wang Y, Hone DWE, Wang Y, Xu X \& Zhang F. 2014. The vertebrates of the Jurassic Daohugou Biota of northeastern China. Journal of Vertebrate Paleontology 34:243-280 DOI:10.1080/02724634.2013.787316.

Tomurtogoo O, Windley BF, Kröner A, Badarch G \& Liu DY. 2005. Zircon age and occurrence of the Adaatsag ophiolite and Muron shear zone, central Mongolia, constraints on the evolution of the Mongol-Okhotsk Ocean, suture and orogeny. Journal of the Geological Society, London 162:125-134.

Traverse A. 1988. Paleopalynology. Unvin Hyman.

$\mathrm{Xu}$ X, Forster CA, Clark JM \& Mo JA. 2006. A basal ceratopsian with transitional features from the Late Jurassic of northwestern China. Proceedings of the Royal Society of London B: Biological Sciences 273:2135-2140. DOI:10.1098/rspb.2006.3566. 
$533 \mathrm{Xu}$ X, You H, Du K \& Han F. 2011. An Archaeopteryx-like theropod from China and the origin of Avialae. Nature 475:465-470. DOI:10.1038/nature10288.

Zhang M, Zhang M, Dai S, Heimhofer U, Wu M, Wang Z \& Pan B. 2014. Palynological records from two cores in the Gongpoquan Basin, central East Asia: Evidence for floristic and climatic change during the Late Jurassic to Early Cretaceous. Review of Palaeobotany and Palynology 204:1-17 DOI:10.1016/j.revpalbo.2014.02.001.

Zheng XT, You HL, Xu X \& Dong ZM. 2009. An Early Cretaceous heterodontosaurid dinosaur with filamentous integumentary structures. Nature 458:333-336 DOI:10.1038/nature07856.

Zhou Z, Jin F \& Wang Y. 2010. Vertebrate assemblages from the middle-late Jurassic Yanliao Biota in Northeast China. Earth Science Frontiers 17:252-254.

Zorin YA. 1999. Geodynamics of the western part of the Mongolia-Okhotsk collisional belt, Trans-Baikal region (Russia) and Mongolia. Tectonophysics 306:33-56 DOI:10.1016/S0040-1951(99)00042-6.

Zorin YA, Zorina LD, Spiridonov AM \& Rutshtein IG. 2001. Geodynamic setting of gold deposits in eastern and central Trans-Baikal (Chita Region, Russia). Ore Geology Reviews 17:215-232 DOI:10.1016/S0169-1368(00)00015-9. 


\section{Figure 1}

Location of the studied area.

(A) Position of Kulinda locality with respect to the Mongol-Okhotsk suture (modified with permission from Tomurtogoo et al., 2005). (B) Geological map of the Kulinda region (redrawn with permission from Kozlov et al., 1998). According to the map, Kulinda is situated in the Upper Jurassic of the Ukurey Formation. 

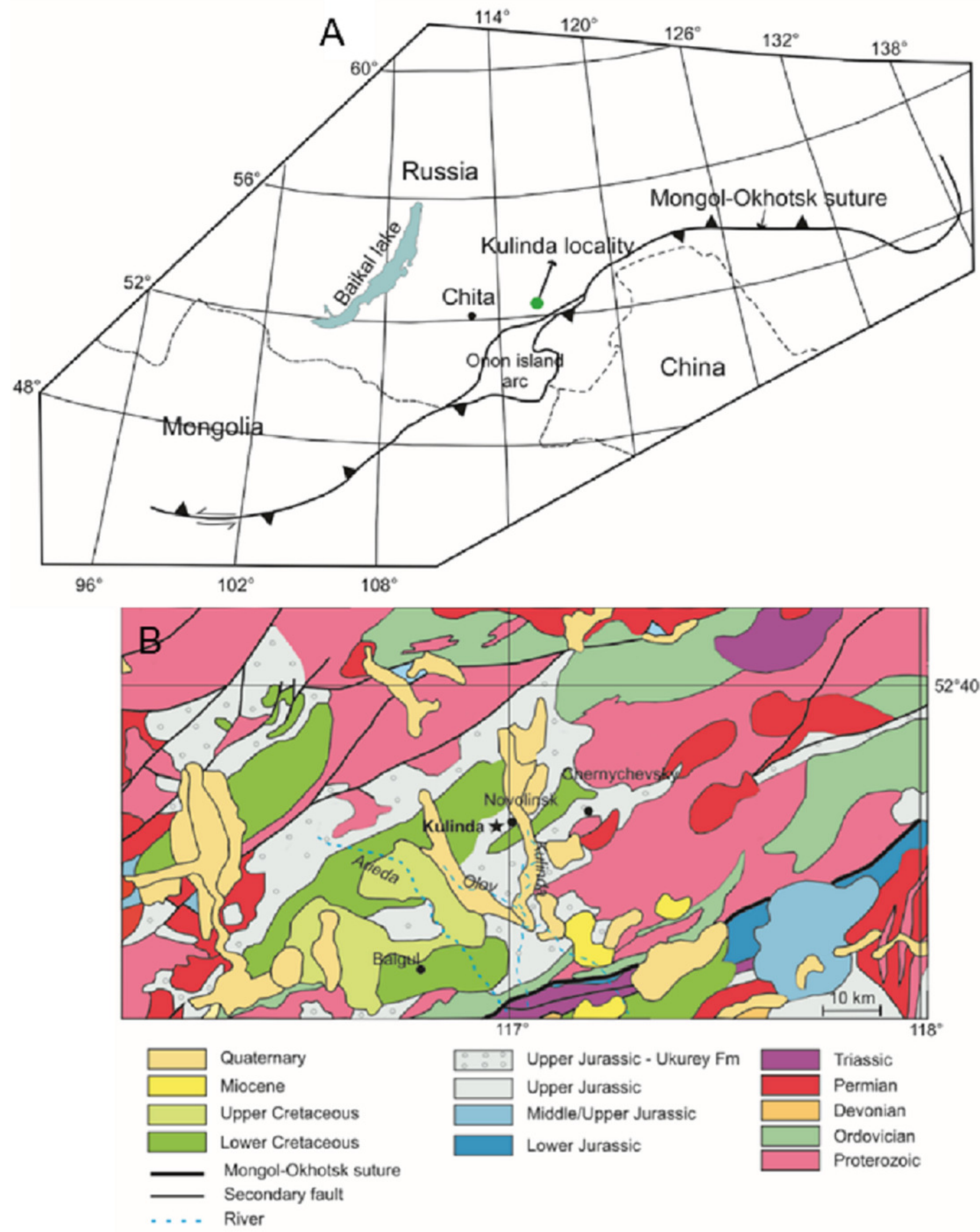


\section{Figure 2}

Lithological section of the Kulinda dinosaur locality in the Ukurey Formation.

(A) Composite stratigraphic log of the three trenches and the position of the bone beds. (B) Schematic location of the trenches excavated on the hillslope. (C) Photograph showing the location of the three parallel trenches on site (photo credit: A. Cincotta). The locations of the detrital samples used for dating are marked by an arrow. 

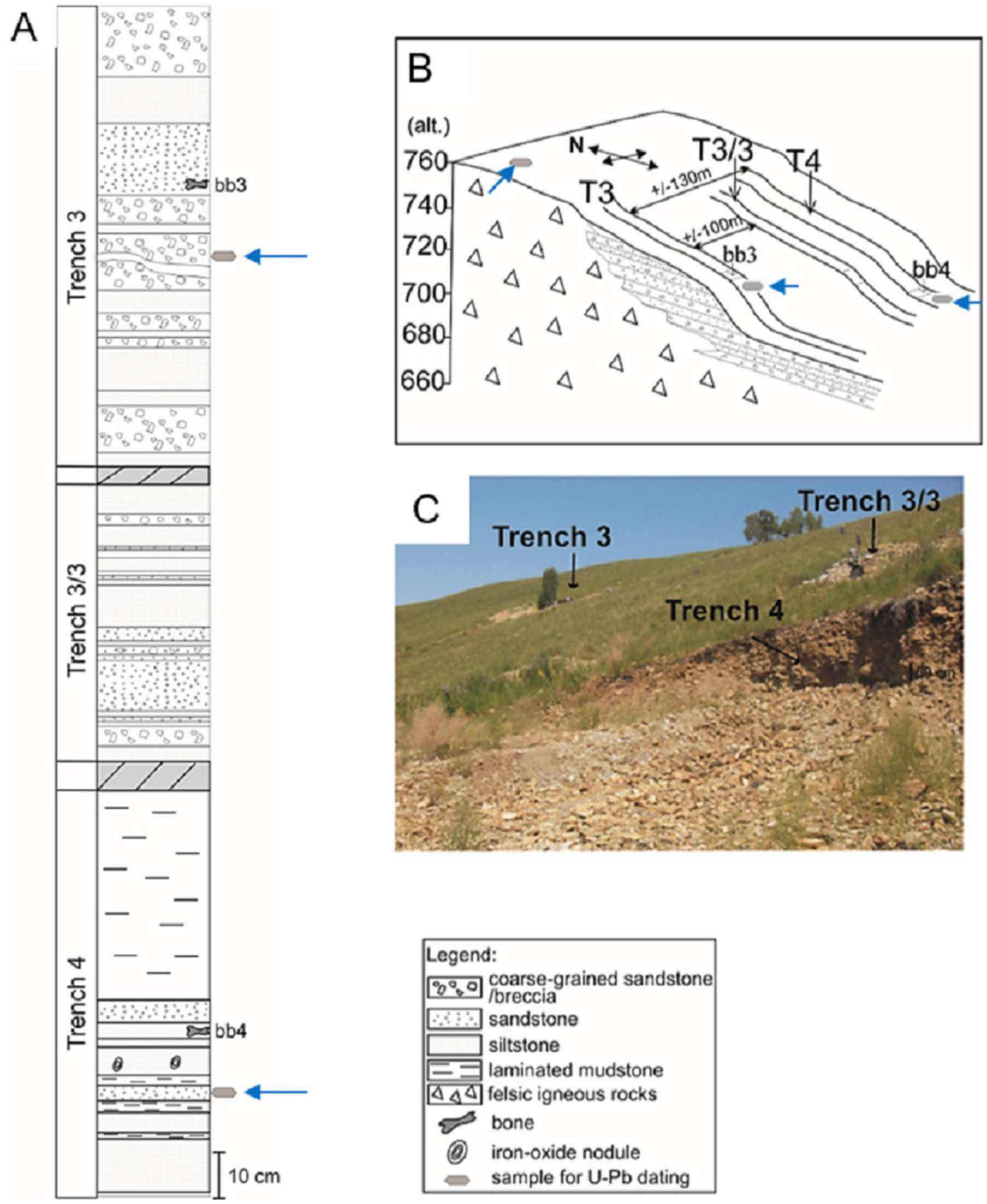

\begin{tabular}{|c|c|}
\hline Legen & \\
\hline 800 & $\begin{array}{l}\text { Coarse-grained sandston } \\
\text { /breccia }\end{array}$ \\
\hline $2: 8$ & sandstone \\
\hline & siltstone \\
\hline EZ & laminated mudstone \\
\hline$\Delta \Delta \Delta$ & felsic igneous rocks \\
\hline 2 & bone \\
\hline (2) & $\begin{array}{l}\text { iron-oxide nodule } \\
\text { sample for } \mathrm{U}-\mathrm{Pb} \text { dating }\end{array}$ \\
\hline
\end{tabular}


Figure 3

Probability curve based on the LA-ICP-MS data performed on zircons and monazites.

Two age populations (i.e. peaks) can be discriminated from this curve.

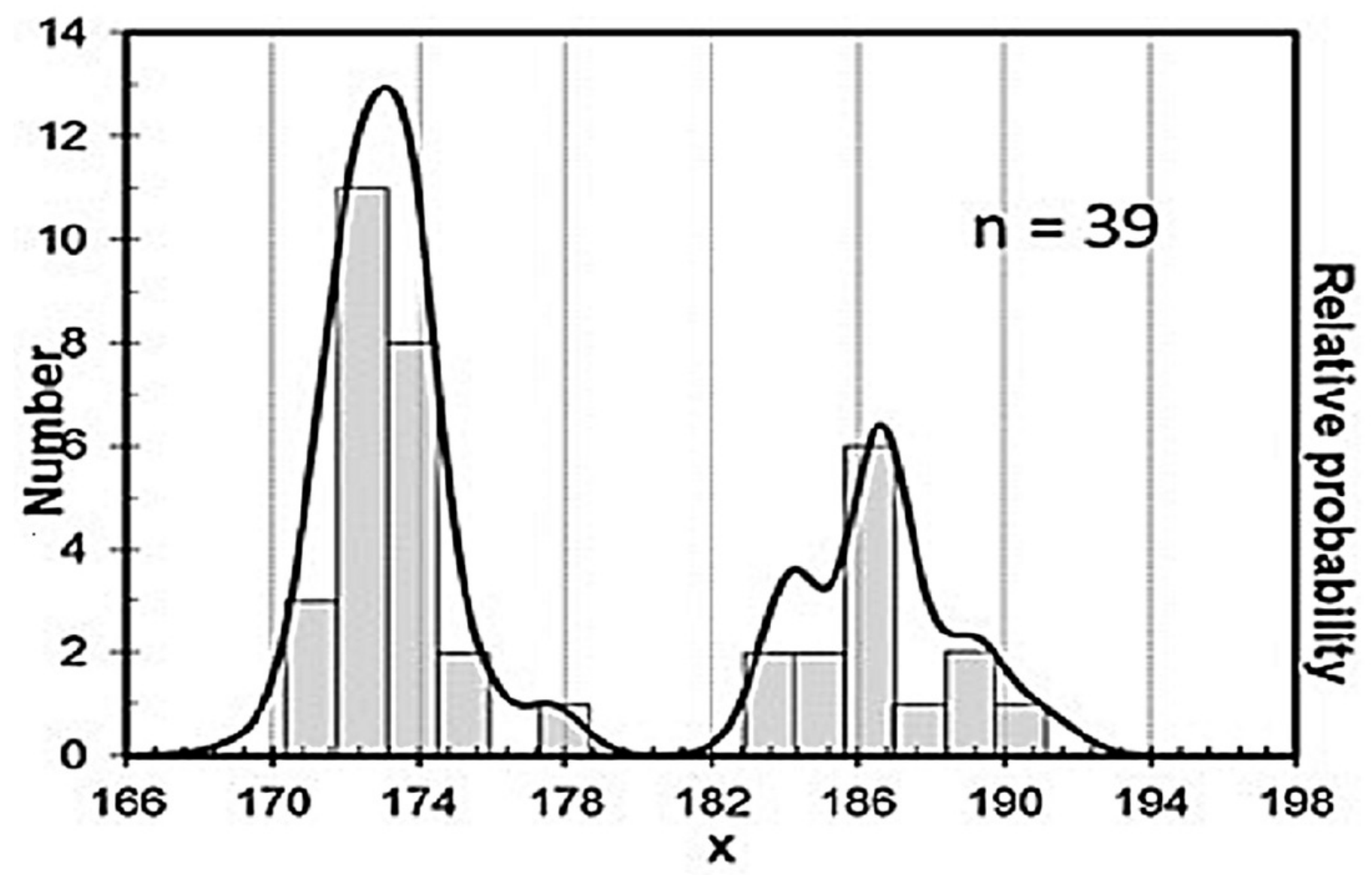




\section{Figure 4}

Concordia diagrams for the three samples collected at Kulinda.

(A) Zircons and monazites collected from the granite. (B) Zircons collected from a sample situated above bone bed 3 in trench 3. (C) Zircons collected from a sample situated below bone bed 4 in trench 4 . 
A

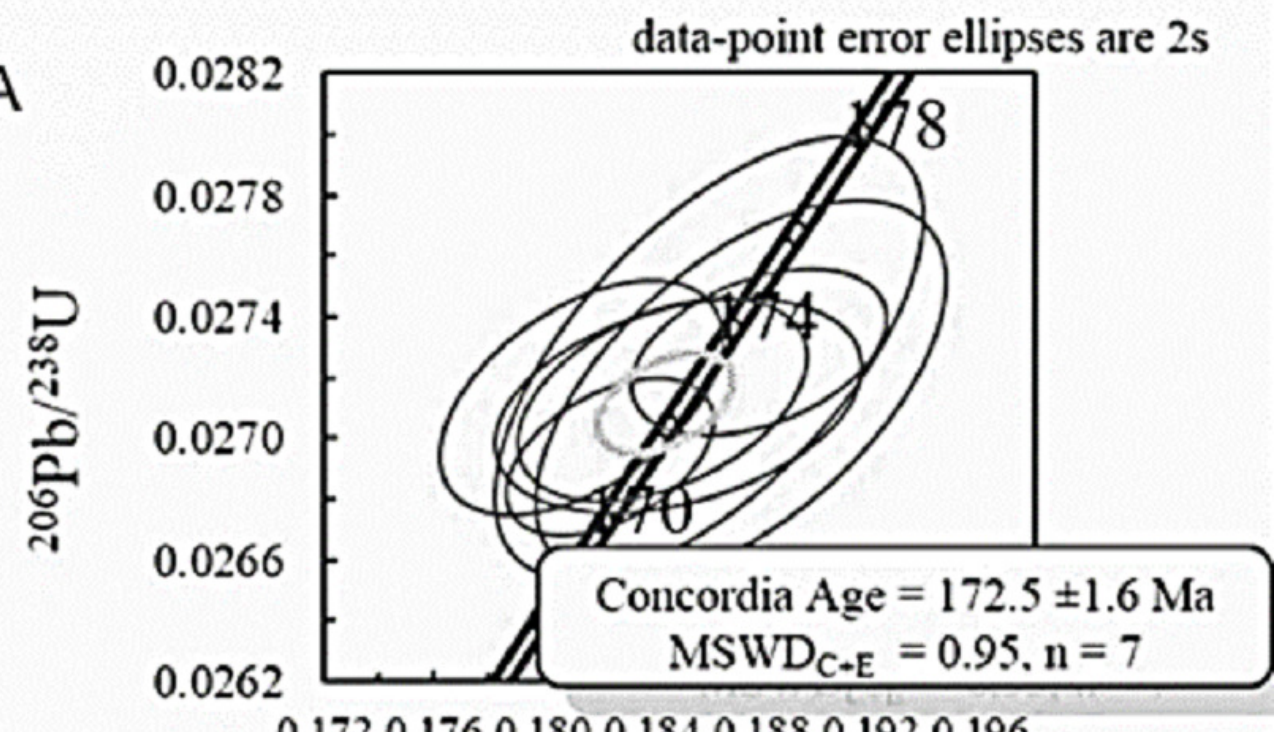

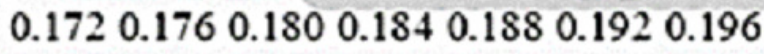

B

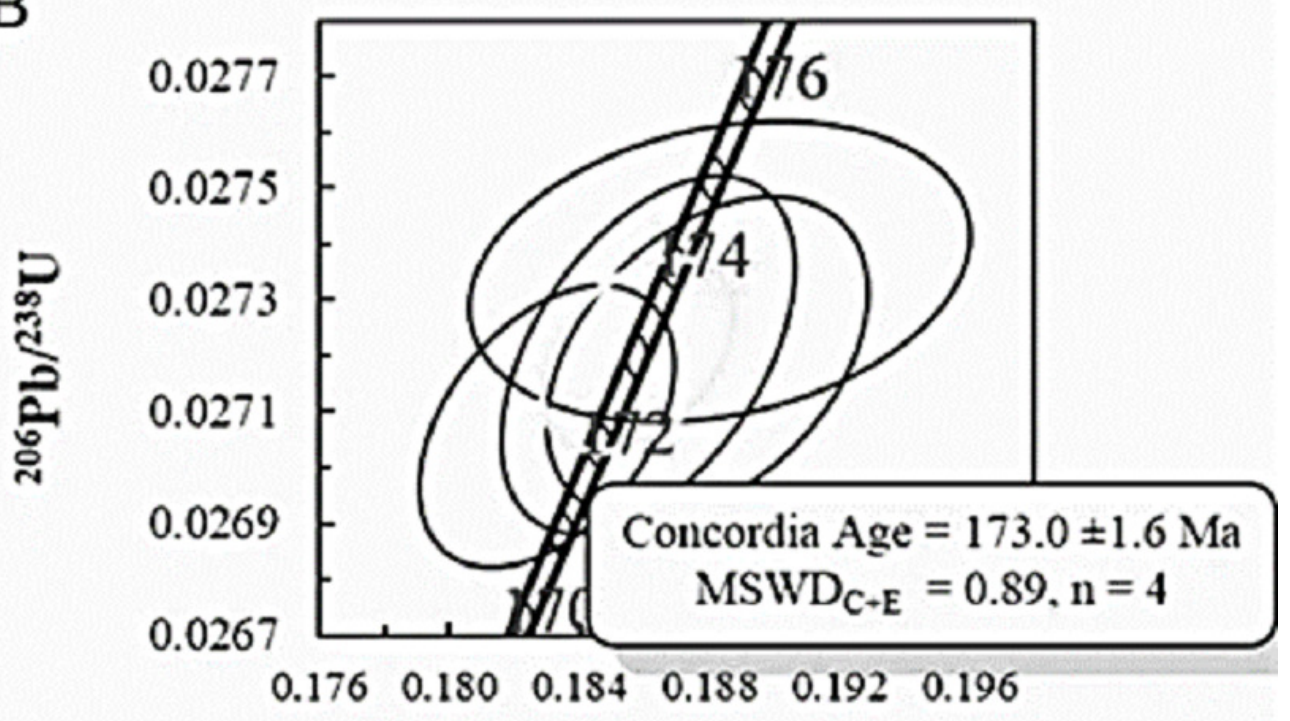

C

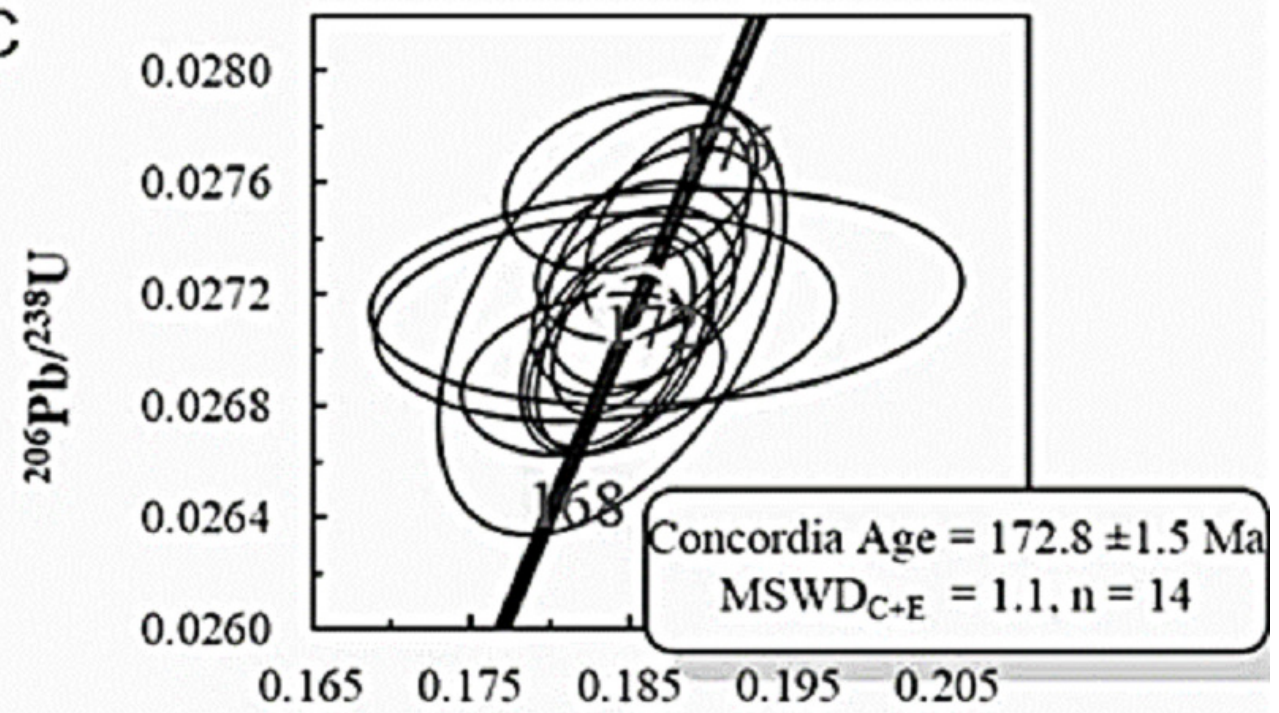


Figure 5

Palynomorph distribution in the Kulinda deposits.

Legend: 1 - coarse sandstone/breccia, 2 - sandstone, 3 - siltstone, 4 - laminated mudstone, 5 - non-correlated part of the stratigraphic section, 6 - bones, 7 - iron-oxide nodules, 8 abundances of the palynomorphs.

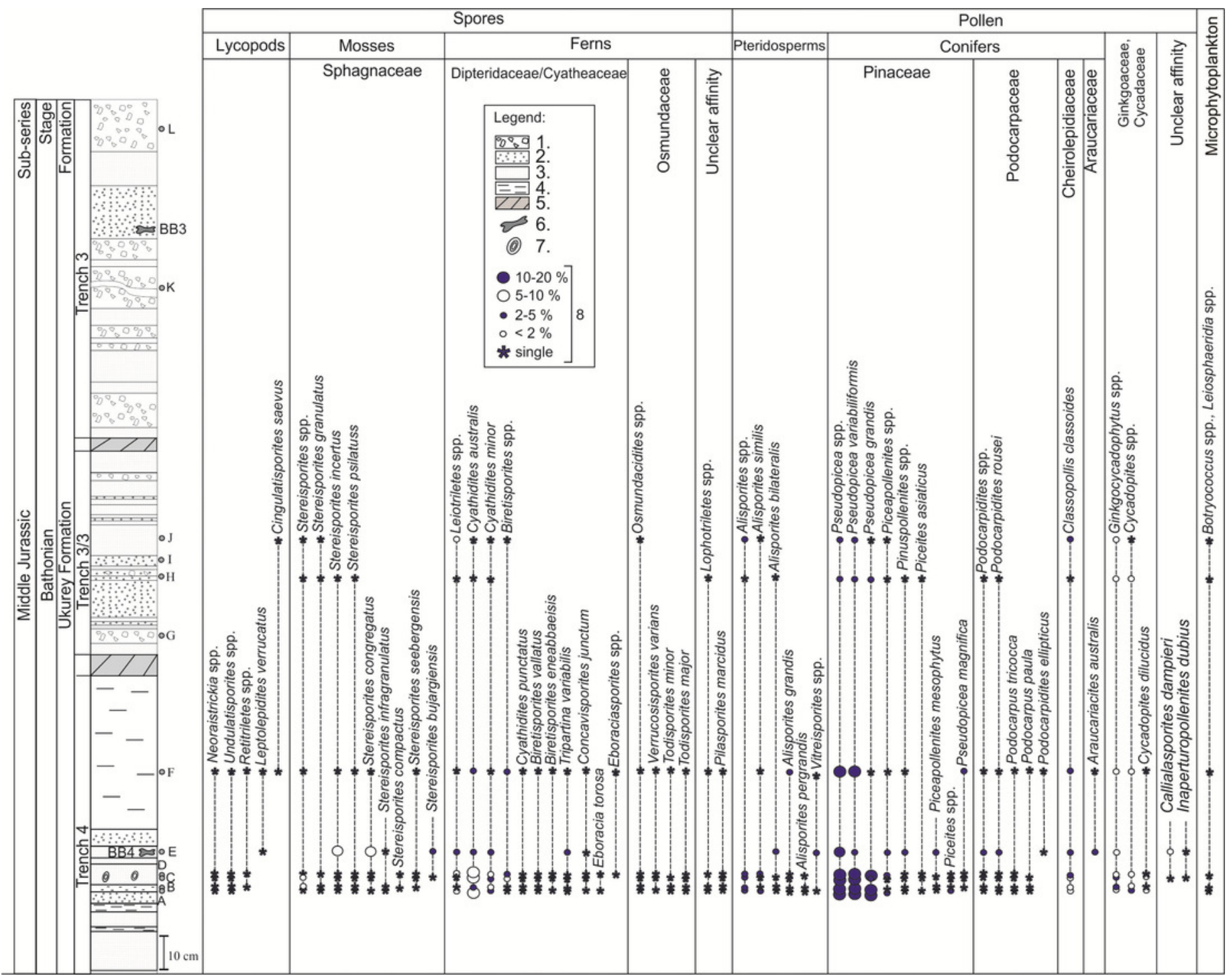




\section{Figure 6}

Selected palynomorphs from the trench exhibiting the dinosaur bones and feather-like structures.
(A) Alisporites similis (Balme) Dettmann. (B) Piceapollenites mesophyticus (Bolchovitina)

Petrosjanz. (C) Osmundacidites jurassicus (Kara-Mursa) Kuzitschkina. (D) Cyathidites minor

Couper. (E) Protopinus subluteus Bolchovitina. (F) Pseudopicea variabiliformis Bolchovitina.

(G) Biretisporites eneabbaensis Backhouse. (H) Podocarpidites rousei Pocock. (I)

Ginkgocycadophytus sp. (J) Stereisporites bujargiensis (Bolchovitina) Schulz. (K) Pseudopicea grandis (Cookson) Bolchovitina. (L) Podocarpus tricocca (Maljavkina) Bolchovitina. (M) Leiosphaeridia sp. (N) Classopollis classoides Pflug. (O) Alisporites bisaccus Rouse. (P) Protoconiferus funarius (Naumova) Bolchovitina. (Q) Pseudopicea magnifica Bolchovitina. (R) Stereisporites granulatus Tralau. (S) Pinus divulgata Bolchovitina. (T) Leiotriletes subtilis Bolchovitina. (U) undetermined spore taxon resembling Aequitriradites norrisii Backhouse. (V) Stereisporites sp. (W) Tripartina variabilis Maljavkina. (X) Stereisporites incertus (Bolchovitina) Semenova. (Y) Leiotriletes sp. Scale bars $=20 \mu \mathrm{m}$. 

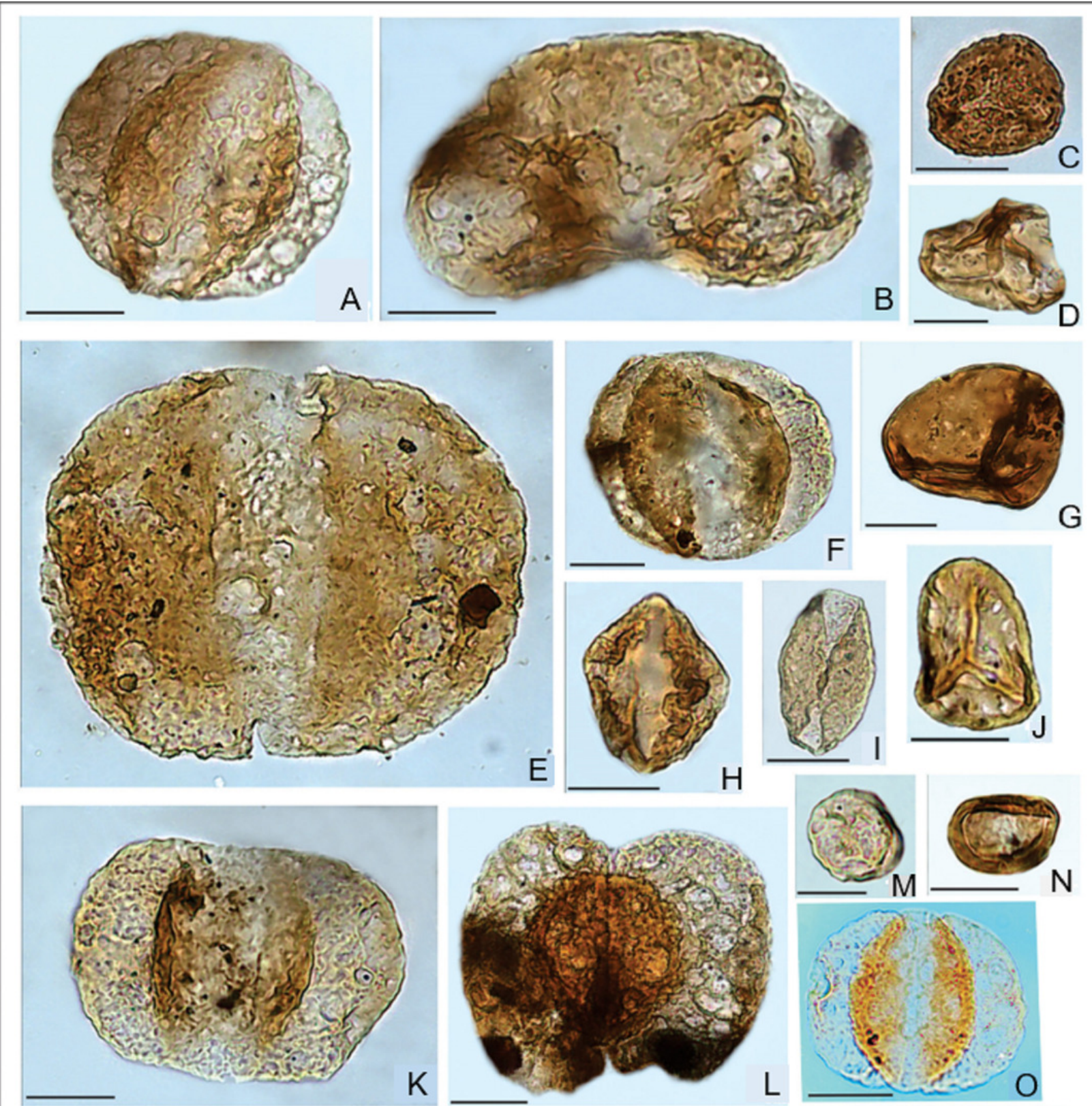

$G$

H
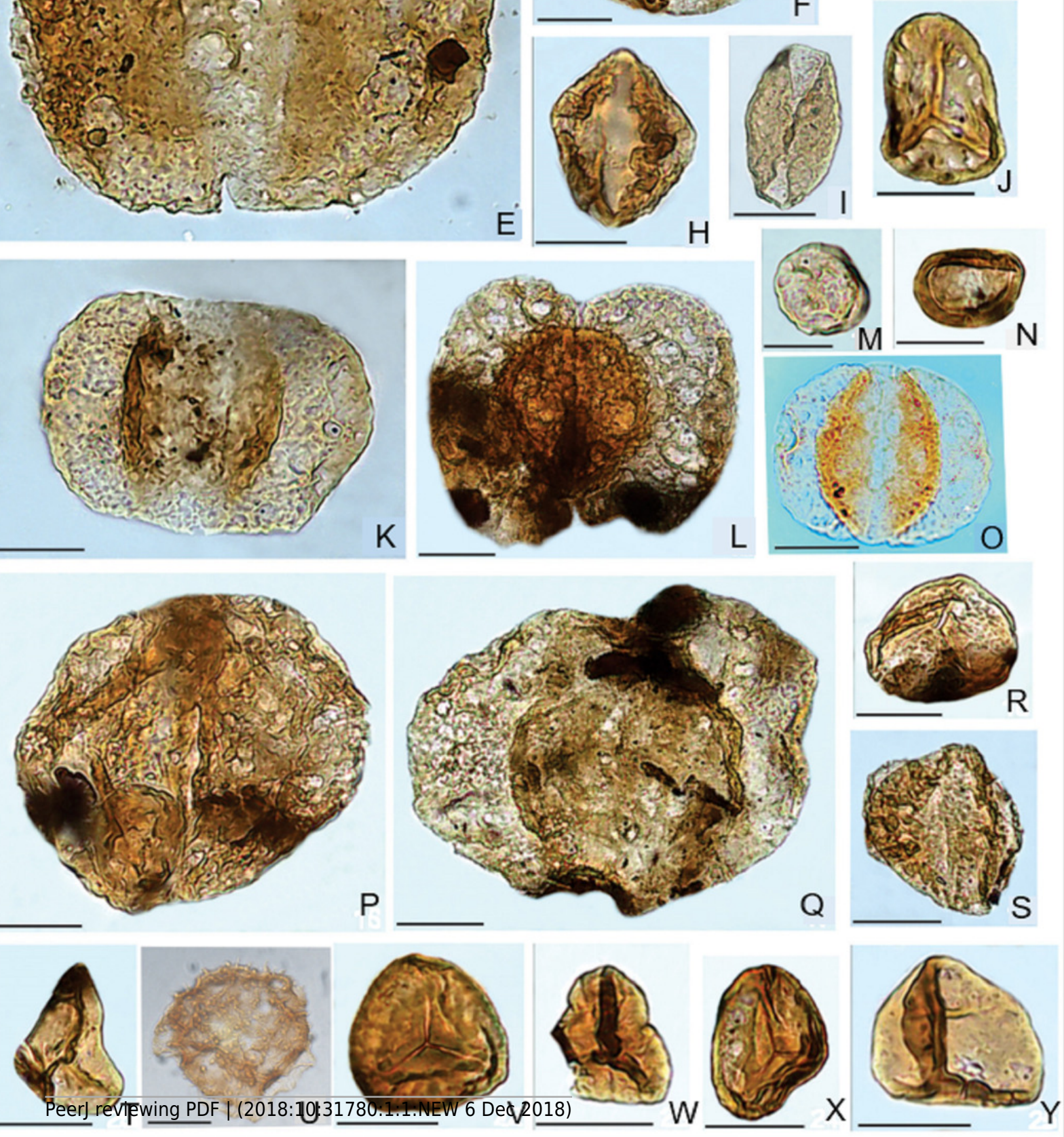